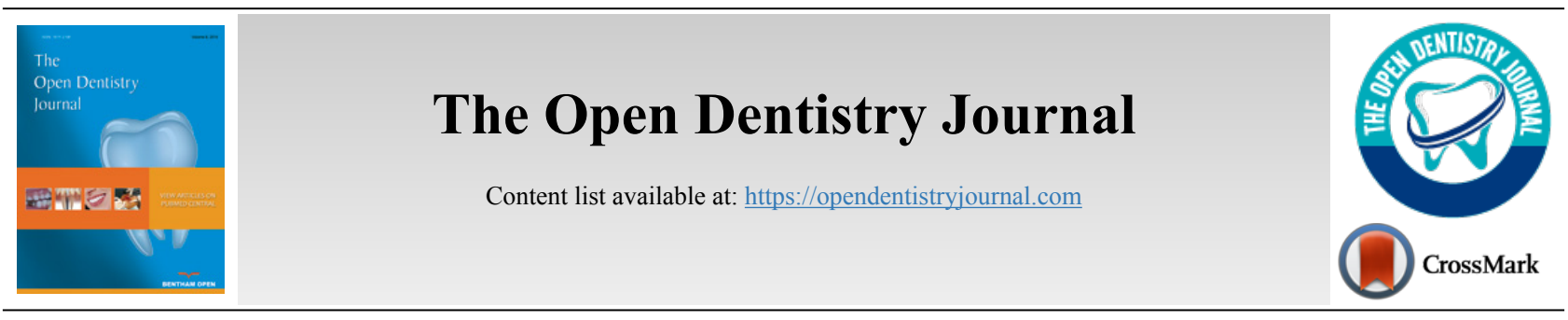

SYSTEMATIC REVIEW

\title{
Effect of Drugs on Orthodontic Tooth Movement in Human Beings: A Sys- tematic Review of Randomized Clinical Trials
}

\author{
Khaled Khalaf* and Mahmoud Mando \\ Department of Orthodontics, College of Dental Medicine (Building M28), University of Sharjah, PO Box 27272, Sharjah, United Arab Emirates
}

\begin{abstract}
:
Background:

Orthodontic tooth movement represents a series of events at both cellular and molecular levels which in turn stimulates inflammatory pathway to induce tooth movement. Some drugs taken by patients have a negative effect which can block this pathway, on the other hand, others may influence these events and reduce treatment time.

Search Methods:

A search strategy was implemented using both manual hand search and electronic databases, including Cochrane database of clinical trials, PubMed, ScienceDirect and Scopus. The risk of biased eligible studies to be included in the final analysis was assessed independently by two authors using Cochrane risk of bias tool.

Results:

A total of 491 articles were identified in both manual and electronic searches as well as by checking the reference lists of articles to be included in the study. After reviewing the titles, abstracts and full-text articles, only 8 RCTs met the inclusion criteria, and thus, were included in the final analysis. Six out of the 8 RCTs were assessed as of low quality. No statistical methods were employed to combine the studies due to the heterogeneities of the studies and the low level of evidence.

\section{Conclusion:}

Acetylsalicylic acid and ibuprofen reduced orthodontic tooth movement whereas paracetamol, Rofecoxib and tenoxicam had no impact on orthodontic tooth movement. Due to the low quality of the studies included, therefore to base our practice on scientific evidence, better-controlled RCTs are needed to investigate the impact of common medications on orthodontic tooth movement.
\end{abstract}

Keywords: Orthodontic tooth movement, Drugs, Medications, Pharmaceutics, Analgesics, Acceleration, Inhibition, Drugs effect.

\begin{tabular}{|c|c|c|c|}
\hline Article History & Received: August 14, 2018 & Revised: November 20, 2018 & Accepted: December 9, 2018 \\
\hline
\end{tabular}

\section{INTRODUCTION}

\subsection{Rationale}

One of the most common disadvantages of orthodontic treatment is being lengthy and thus expensive. When teeth are subjected to orthodontic force, a series of biological events take place to induce tooth movement. First, the applied mechanical force causes interstitial fluid to be expressed through canaliculi and apply pressure on the surrounding ECM and cells. Mechanoreceptors represented by osteocytes in the lining of al-

\footnotetext{
* Address correspondence to this author at the College of Dental Medicine (Building M28), University of Sharjah, PO Box 27272, Sharjah, United Arab Emirates; Tel: +97165057370; E-mail: kkhalaf@sharjah.ac.ae
}

veolar socket and fibroblast in the PDL can detect the strain. This strain on bone ECM and cells result in the stimulation of transmembrane protein called Integrins which attach the cell cytoskeleton to its extracellular matrix $[1,2]$. Integrin stimulation activates the signal transducing pathway triggering osteocyte differentiation into osteoblast and osteoclast to build and resorb bone. As a result, intracellular calcium increases, promoting the activation of phospholipase A2 which is responsible for the hydrolysis of glycerophospholipids to yield arachidonic acid. Then arachidonic acid is converted by Cyclooxygenase (COX) enzymes to produce prostaglandins which play the key role in the inflammatory process [1 - 3]. Orthodontists often prescribe drugs to manage pain and discomfort resulting from orthodontic treatment, mostly 
acetylsalicylic acid, ibuprofen, and paracetamol [4 - 6], which in turn block prostaglandin synthesis and may result in slower tooth movement. On the other hand, many methods including biological methods [7 - 9], device-assisted treatment [10 - 14] and surgical approach [15-18] have been investigated recently to reduce orthodontic treatment time by accelerating tooth movement. Therefore, the aim of this study was to investigate the effect of various drugs on orthodontic tooth movement.

\subsection{Objectives}

By summarizing evidence from existing randomized clinical trials, the aim of this systematic review was to investigate the effect of commonly used drugs on orthodontic tooth movement and whether some of them may play a role as a minimally invasive procedure to accelerate orthodontic tooth movement and reduce treatment time.

\section{MATERIALS AND METHODS}

\subsection{Protocol and Registration}

The present systematic review was conducted using the Prisma checklist guidelines and registered in Prospero (International Prospective Register of Systematic Reviews) under the registration number CRD42019 115908.

\subsection{Information Sources and Search Strategy}

A comprehensive search strategy was implemented using both manual and electronic search methods in order to identify both indexed and non-indexed articles in databases as well as to reduce the possibility of excluding relevant studies by chance. The online database search strategy incorporated the following databases: Cochrane database of clinical trials, PubMed, ScienceDirect and Scopus until April 2018 using the following keywords:

- (tooth or teeth or orthodontic*) and move* and (drug* or medic*);

- (tooth or orthodontic) and movement and (drug or medication);

- (drug or medication) and (tooth or orthodontic*) and movement;

- (drug* OR medication OR pharmaceutical OR analgesics OR non-steroidal anti-inflammatory drugs OR bisphosphonate OR relaxin OR fluoride OR hormone OR vitamin) AND ("tooth movement" OR "teeth movement" OR "orthodontic* movement”).

The manual hand search incorporated the following journals:

(1) Journal of Orthodontics (2005-2018);

(2) European Journal of Orthodontics (2009-2018);

(3) American Journal of Orthodontics and Dento-facial Orthopedics (2000-2018);

(4) Angle Orthodontist (1990-2018).

\subsection{Eligibility Criteria}

Articles were comprehensively examined against the inclusion and exclusion criteria and only studies carried out on humans and specifically randomized clinical trials were inclu- ded in the systematic review. Abstracts, titles and subsequently full texts of potential articles were examined carefully and independently by two authors to make sure they were eligible to meet the inclusion criteria. Furthermore, references of all reviewed articles were assessed carefully for their eligibility to meet the inclusion criteria.

\subsection{Risk of Bias in Individual Trials}

All articles included in the study were reviewed independently by two authors in order to assess the level of bias using Cochrane risk of bias tool shown in Table 1. which is an assessment tool that entails quality assessment based on five factors including selection bias (allocation concealment and methods of randomization), detection bias, performance bias, reporting bias and attrition bias [19]. Using the Grade approach (Grading of Recommendations Assessment, Development and Evaluation), the overall quality of evidence was assessed based on five factors: risk of bias, inconsistency, imprecision, indirectness and publication bias. The grade ratings of high, moderate, low, very-low quality evidence reflect how confident we are that the true effect lies close to the estimated effect in the systematic review [20].

\section{RESULTS}

\subsection{Study Selection}

The flowchart in Fig. (1) identifies the included and excluded articles at each stage. 507 articles were assessed, including 489 articles from the electronic databases, 16 from the manual hand search and 2 articles from the reference lists. 16 articles were duplicates, and 346 did not relate to the research question, thus leaving 145 articles for potential inclusion in the study. Following the inspection of the full text of these articles, 116 were excluded as they were experimental animal studies and further 21 were also excluded due to different reasons (12 reviews, 5 systematic reviews, 1 cohort and 3 case reports). This means only 8 randomized clinical trials were included in the review for further analysis. The process of searching and selection of studies to be included in the review was carried out independently and in duplicate by the 2 authors and any disagreement was resolved through a discussion between them. The kappa statistic for agreement between the reviewers was 0.86 .

\subsection{Risk of Bias Within Studies}

Using the Cochrane risk of bias tool, the quality of evidence of all papers included was ranging between low to high-quality evidence. Only two of the included studies had a high-quality evidence as they were double-blinded randomized clinical trials with a clear method of randomization and allocation concealment. The remaining 6 papers had a low-quality evidence due to either not stating the method of randomization or blinding the participants and personnel (Fig. 2). According to the Grade system, the overall quality of evidence was observed to range between low to high (Table 2). However, due to the low evidence of the studies included and their heterogeneities, no formal data synthesis or meta-analysis was undertaken. 
Table 1. The Cochrane Collaboration's tool for assessing risk of bias.

\begin{tabular}{|c|c|c|}
\hline Domain & Support for Judgement & Review Authors' Judgement \\
\hline Selection bias. & - & - \\
\hline $\begin{array}{l}\text { Random sequence } \\
\text { generation. }\end{array}$ & $\begin{array}{l}\text { Describe the method used to generate the allocation sequence in sufficient } \\
\text { detail to allow an assessment of whether it should produce comparable } \\
\text { groups. }\end{array}$ & $\begin{array}{l}\text { Selection bias (biased allocation to } \\
\text { interventions) due to inadequate } \\
\text { generation of a randomized sequence. }\end{array}$ \\
\hline Allocation concealment. & $\begin{array}{l}\text { Describe the method used to conceal the allocation sequence in sufficient } \\
\text { detail to determine whether intervention allocations could have been } \\
\text { foreseen in advance of, or during, enrolment. }\end{array}$ & $\begin{array}{l}\text { Selection bias (biased allocation to } \\
\text { interventions) due to inadequate } \\
\text { concealment of allocations prior to } \\
\text { assignment. }\end{array}$ \\
\hline Performance bias. & - & - \\
\hline $\begin{array}{l}\text { Blinding of participants and } \\
\text { personnel } \\
\text { Assessments should be made } \\
\text { for each main outcome (or } \\
\text { class of outcomes). }\end{array}$ & $\begin{array}{l}\text { Describe all measures used, if any, to blind study participants and personnel } \\
\text { from knowledge of which intervention a participant received. Provide any } \\
\text { information relating to whether the intended blinding was effective. }\end{array}$ & $\begin{array}{l}\text { Performance bias due to knowledge of } \\
\text { the allocated interventions by } \\
\text { participants and personnel during the } \\
\text { study. }\end{array}$ \\
\hline Detection bias. & - & - \\
\hline $\begin{array}{c}\text { Blinding of outcome } \\
\text { assessment } \\
\text { Assessments should be made } \\
\text { for each main outcome (or } \\
\text { class of outcomes). }\end{array}$ & $\begin{array}{l}\text { Describe all measures used, if any, to blind outcome assessors from } \\
\text { knowledge of which intervention a participant received. Provide any } \\
\text { information relating to whether the intended blinding was effective. }\end{array}$ & $\begin{array}{l}\text { Detection bias due to knowledge of the } \\
\text { allocated interventions by outcome } \\
\text { assessors. }\end{array}$ \\
\hline Attrition bias. & - & - \\
\hline $\begin{array}{l}\text { Incomplete outcome data } \\
\text { Assessments should be made } \\
\text { for each main outcome (or } \\
\text { class of outcomes). }\end{array}$ & $\begin{array}{c}\text { Describe the completeness of outcome data for each main outcome, } \\
\text { including attrition and exclusions from the analysis. State whether attrition } \\
\text { and exclusions were reported, the numbers in each intervention group } \\
\text { (compared with total randomized participants), reasons for } \\
\text { attrition/exclusions where reported, and any re-inclusions in analyses } \\
\text { performed by the review authors. }\end{array}$ & $\begin{array}{l}\text { Attrition bias due to amount, nature or } \\
\text { handling of incomplete outcome data. }\end{array}$ \\
\hline Reporting bias. & - & - \\
\hline Selective reporting. & $\begin{array}{c}\text { State how the possibility of selective outcome reporting was examined by } \\
\text { the review authors, and what was found. }\end{array}$ & $\begin{array}{l}\text { Reporting bias due to selective } \\
\text { outcome reporting. }\end{array}$ \\
\hline Other bias. & - & - \\
\hline Other sources of bias. & $\begin{array}{l}\text { State any important concerns about bias not addressed in the other domains } \\
\text { in the tool. } \\
\text { If particular questions/entries were pre-specified in the review's protocol, } \\
\text { responses should be provided for each question/entry. }\end{array}$ & $\begin{array}{l}\text { Bias due to problems not covered } \\
\text { elsewhere in the table. }\end{array}$ \\
\hline
\end{tabular}

Table 2. A summary of GRADE's approach to rate the overall quality of evidence.

\begin{tabular}{|c|c|c|c|c|c|c|}
\hline Article & Risk of Bias & Inconsistency & Indirectness & Imprecision & Publication Bias & Overall Quality of Evidence \\
\hline Mcgorray et al., 2011 [21] & Not serious & Not serious & Not serious & Not serious & None & 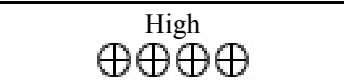 \\
\hline Arantes et al., 2009 [22] & Not serious & Not serious & Not serious & Not serious & None & $\oplus \stackrel{\text { High }}{\oplus \oplus}$ \\
\hline Hussain et al., 2011 [23] & Very serious & Not serious & Not serious & Not serious & None & \\
\hline Yamasaki et al., 1984 [24] & Very serious & Not serious & Not serious & Not serious & None & \\
\hline Patil et al., 2005 [25] & Very serious & Not serious & Not serious & Not serious & None & \\
\hline $\begin{array}{l}\text { Sari et al., } \\
2004 \text { [26] }\end{array}$ & Very serious & Not serious & Not serious & Not serious & None & \\
\hline $\begin{array}{c}\text { Shetty et al., } \\
2013 \text { [27] }\end{array}$ & Very serious & Not serious & Not serious & Not serious & None & $\bar{I}$ \\
\hline Karadeniz et al., 2011 [28] & Very serious & Not serious & Not serious & Not serious & None & Lo \\
\hline
\end{tabular}



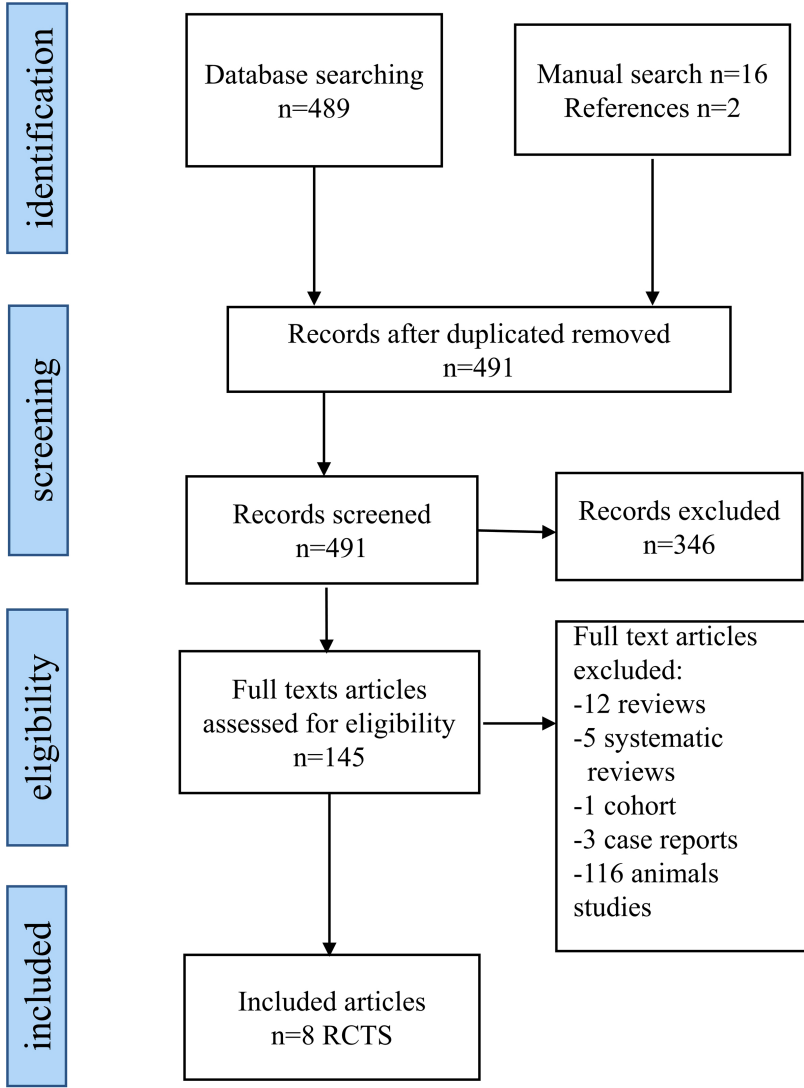

Included articles $\mathrm{n}=8$ RCTS

Fig. (1). A flow chart describing the search methodology and numbers of articles included/excluded at each stage.

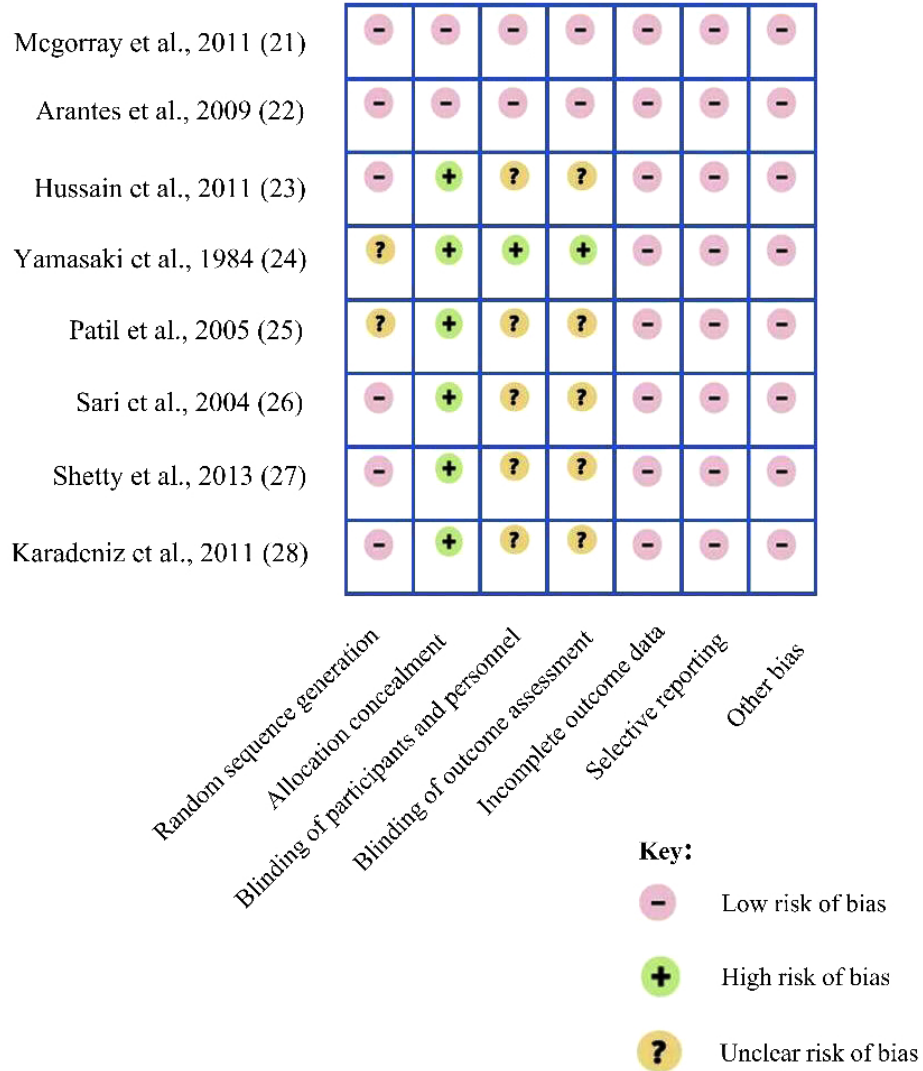

Fig. (2). Quality assessment of the studies included in the systematic review using "Cochrane risk of bias" tool. 


\subsection{Results of Individual Studies}

\subsubsection{Relaxin}

The first clinical trial is a randomized double-blinded study in which 39 adults who required a minor maxillary alignment received a series of 4 maxillary aligners, each subject received a weekly $0.2 \mathrm{ml}$ injection of Relaxin or placebo over 8 weeks period to the target teeth. Tooth movement was calculated weekly on a PVS impression that was scanned and digitalized. After completing 8 weeks of orthodontic treatment, there was no statistical significance between both the groups. Similarly, there was no statistically significant difference with regard to the relapse of orthodontic treatment over 4 weeks post-treatment between the Relaxin and placebo groups [21].

\subsubsection{Tenoxicam}

Another double-blinded RCT investigated the effect of Tenoxicam in controlling pain and its influence on orthodontic movement of the upper canine in 36 patients who had an orthodontic indication for bilateral retraction of the upper canine teeth. Group A patients received one tablet of $20 \mathrm{mg}$ of Tenoxicam 45 minutes before the orthodontic activation process and one tablet of placebo after activation. Group B patients received the opposite treatment, and Group $\mathrm{C}$ received one tablet of placebo 45 minutes before the procedure and one tablet of placebo just afterward. Subsequently, after 30 days interval, there was no statistically significant difference in orthodontic tooth movement between the 3 groups, but patients in groups A and B had lower pain intensity than in those in group C. Thus, Tenoxicam used only once daily was shown to be effective for pain control, without having a significant influence on orthodontic tooth movement [22].

\subsubsection{Calcitriol (Vitamin D3)}

In this RCT, 15 patients who required bilateral maxillary canine retraction were randomly allocated into three groups, each treated with a specific dose of vitamin D3 $(15 \mu \mathrm{g}, 25 \mu \mathrm{g}$ and $40 \mu \mathrm{g}$, respectively). In the experimental side, a specific dose of Calcitriol was injected locally in the distal side of the canine, while the control side received $0.2 \mathrm{ml}$ of vehicle. As a result, the experimental site in groups 1 and 3 showed about $10 \%$ higher clinical net rate of canine movement compared to the control site. In group 2, the experimental site demonstrated $51.0 \%$ increase in OTM movement compared to the control site. This suggests that locally injected calcitriol, in a specific dose is cost-effective in increasing orthodontic tooth movement in humans without any side effect [23].

\subsubsection{Prostaglandin E1}

Two studies have investigated the effect of PGE1 on orth-

odontic tooth movement. In the first one, the authors divided patients who required orthodontic treatment with first premolars extraction into 3 phases in which the injection of PGE1 $(10 \mu \mathrm{g})$ was given to the experimental side (a premolar in phase 1 and a canine in phase 2 and 3) and a vehicle to the control side (a premolar in phase 1 and a canine in phase 2 and 3 ). The speed of tooth movement in the experimental side of all cases exceeded that of the control side. In most of the cases, the rate of tooth movement on the experimental side was doubled without side effects [24].

In the second study, 15 patients who required extraction of first premolars for the correction of their malocclusions were injected a $1 \mathrm{~g}$ of PGE1 in a solution in the right upper quadrant, and a vehicle in the left side. Injections were given on the $1^{\text {st }}$ day, $6^{\text {th }}$ day and $17^{\text {th }}$ day of the start of canine retraction. The mean values of tooth movement in a 2 months period for the right and left canines were $3.5 \mathrm{~mm}$ and $2 \mathrm{~mm}$ respectively, with a corresponding ratio of 1.7:1 respectively. These results show a significant increase in tooth movement upon PGE1 injection [25].

\subsubsection{Acetylsalicylic Acid vs Rofecoxib}

This study compared the effect of acetylsalicylic acid and Rofecoxib on PGE2 content in the gingival crevicular fluid in 36 patients with class2 division1 malocclusion receiving orthodontic treatment with maxillary first premolars extraction. 36 patients were divided randomly into three groups. The first group received a $500 \mathrm{mg}$ of acetylsalicylic acid 3 times daily, the second group received $25 \mathrm{mg}$ of Rofecoxib on the same day of activation and $12.5 \mathrm{mg}$ on the next day, the third group was the control group and was administered no analgesics. In all groups, the levels of PGE2 increased at 24 and 48 hours and decreased by 168 hours. When comparing the two drugs, it was found that the inhibition effect of acetylsalicylic acid on PGE2 was greater than Rofecoxib, which emphasizes that Rofecoxib is suitable to use as an analgesic to control pain without affecting the outcome of orthodontic treatment [26].

\subsubsection{Ibuprofen vs Acetaminophen}

This study assessed the effect of Ibuprofen and Acetaminophen on PGE2 levels in 42 patients who received fixed orthodontic treatment in whom maxillary $1^{\text {st }}$ premolars were planned for extraction. Subjects were divided into 3 groups, the first group received $400 \mathrm{mg}$ of ibuprofen 3 times per day for 2 days, the second group was administered acetaminophen 500 $\mathrm{mg}$ three times a day for 2 days, and the third group was the control group and received no analgesic. The levels of PGE2 obtained at 24 and 48 hours from the first group which received Ibuprofen was statistically significant when compared to the other groups, unlike Acetaminophen which had no effect on PGE2 synthesis when compared to the control group [27].

\subsubsection{Fluoride}

This study evaluated the effect of Fluoride concentration in drinking water in 48 patients who required extraction of 96 upper first premolars using both light $(25 \mathrm{~g})$ and heavy forces (225 g) delivered buccally to the upper first premolars. Patients were selected from two different cities in Turkey with low and high fluoride concentrations of 0.05 and 2 ppm, respectively. The combination of the level of force and fluoride concentration resulted in a comparison between four groups as follows:

(1) Group 1 high Fluoride-heavy force (HH).

(2) Group 2 low Fluoride-heavy force (LH).

(3) Group 3 high Fluoride-light force (HL). 
(4) Group 4 low Fluoride-light force (LL).

2D and 3D evaluation method showed that the greatest tooth movement was in group $1(\mathrm{HH})$ followed by group 3 (HL), group 2 (LH) and lastly group 4 (LL) as the average rate of tooth movement was found to be greater in the heavy force and high Fluoride intake group (Group 1) which suggests that both heavy force and high Fluoride intake can accelerate tooth movement [28] (Table 3).

\section{DISCUSSION}

\subsection{Summary of Evidence}

This is the first systematic review to be carried out in humans trying to address a very important clinical question i.e. the effect of commonly used medications on orthodontic tooth movement. A systematic review was conducted in 2009 by Bartzela et al., about the effect of medication on orthodontic tooth movement, but considered only a few human studies and most of the studies included were experimental studies on animals [29]. Another systematic review was carried out in 2018 by Makrygiannakis et al., which investigated the effect of common prescription medications on the rate of orthodontic tooth movement included only animal studies [30].

In our systematic review effect of different drugs on orthodontic tooth movement in Humans was investigated, including the dose of each drug used, a method of administration, magnitude of force delivered and methods of evaluating tooth movement. Two clinical trials investigated the effect of PGE1 injections on orthodontic tooth movement which showed a significant acceleration of tooth movement in the injected side compared to the control side even in a very small dosage, whereby in some cases the ratio of tooth movement in the experimental to the control side was almost double. This acceleration in tooth movement is related to the evidence that PGE1 stimulates bone resorption [31]. In addition to bone resorption stimulation, it induces marked changes in the morphology of the alveolar bone including an increase in its vascularity, fibrous replacement and extensive bone matrix loss [32].

It was found that the use of tenoxicam (20 mg once daily) to relieve pain during canine retraction, was effective in controlling pain without interfering with orthodontic tooth movement. Other commonly used analgesics such as Paracetamol and Rofecoxib were similar to the control group and had no effect on the level of PGE2, unlike ibuprofen and acetylsalicylic acid which both reduced PGE2 levels significantly in GCF. This is due to the fact that both ibuprofen and acetylsalicylic acid inhibit Cyclooxygenase (COX) enzyme which is responsible for prostaglandins synthesis [33]. These findings suggest that acetylsalicylic acid and ibuprofen as commonly used medications should be avoided or used with caution during orthodontic treatment, while paracetamol and Rofecoxib were the best in controlling pain without interfering with or having any detriment on orthodontic tooth movement.

Table 3. Summarized published data of the studies included in the systematic review.

\begin{tabular}{|c|c|c|c|c|c|c|c|c|}
\hline Article & \begin{tabular}{|c|} 
Material: \\
Size, \\
Gender, \\
Age \\
(Years), \\
Dropout
\end{tabular} & Drug Used & \begin{tabular}{|c|} 
Dose and \\
Method of \\
Administration
\end{tabular} & $\begin{array}{l}\text { Methods of } \\
\text { Force } \\
\text { Application }\end{array}$ & $\begin{array}{c}\text { Method of } \\
\text { Measurement } \\
\text { of GCF/Tooth } \\
\text { Movement }\end{array}$ & $\begin{array}{c}\text { Observation } \\
\text { Time/Follow-up } \\
\text { Time }\end{array}$ & $\begin{array}{c}\text { Impact of } \\
\text { Medication on } \\
\text { Tooth } \\
\text { Movement }\end{array}$ & $\begin{array}{c}\text { Outcome/Author's } \\
\text { Conclusion }\end{array}$ \\
\hline $\begin{array}{l}\text { Sari et al., } \\
2004 \text { [26] }\end{array}$ & $\begin{array}{c}\bullet \mathrm{N}=36 \\
\text { patients } \\
(18 \\
\text { males/18 } \\
\text { females }) \\
- \text { Mean } \\
\text { age: } 17.6 \\
- \text { No Drop } \\
\text { out }\end{array}$ & $\begin{array}{l}\text { Acetylsalicylic } \\
\text { acid } v s \\
\text { rofecoxib }\end{array}$ & \begin{tabular}{|c|} 
Group 1 \\
received \\
acetylsalicylic \\
acid, 500 mg 3 \\
times daily for 2 \\
days (activation) \\
• Group 2 \\
received \\
rofecoxib $25 \mathrm{mg}$ \\
on the day of \\
activation and \\
12.5 mg on the \\
next day \\
• Group3 \\
(control)
\end{tabular} & $\begin{array}{c}72 \text { maxillary } \\
\text { canine teeth } \\
\text { were distalized } \\
\text { with } 120 \mathrm{~g} \text { of } \\
\text { force delivered } \\
\text { by NiTi } \\
\text { closed-coil } \\
\text { springs }\end{array}$ & $\begin{array}{c}\text { GCF was } \\
\text { obtained at } \\
\text { baseline and } \\
\text { after the } \\
\text { activation of } \\
\text { closed-coil } \\
\text { springs at }(1,2 \text {, } \\
\text { and } 7 \text { days) } \\
\text { using } 4 \text { filter } \\
\text { papers }\end{array}$ & $\begin{array}{c}\text { - Observation } \\
\text { time was } 7 \text { days } \\
\text { - Follow up was } \\
\text { not clear }\end{array}$ & $\begin{array}{l}\text { A statistically } \\
\text { significant } \\
\text { decrease in } \\
\text { PGE2 levels in } \\
\text { acetylsalicylic } \\
\text { acid group at } 24 \\
\text { hours unlike } \\
\text { rofecoxib } \\
\text { which was } \\
\text { similar to } \\
\text { control group }\end{array}$ & $\begin{array}{l}\text { Rofecoxib can be } \\
\text { used during } \\
\text { orthodontic } \\
\text { treatment without } \\
\text { altering tooth } \\
\text { movement }\end{array}$ \\
\hline $\begin{array}{l}\text { Shetty et } \\
\text { al., } \\
2013 \text { [27] }\end{array}$ & $\begin{array}{c}\cdot \mathrm{N}=42 \\
\text { patients } \\
\text { - Mean } \\
\text { age: } 18 \\
\text { - No drop } \\
\text { out }\end{array}$ & $\begin{array}{l}\text { Ibuprofen and } \\
\text { acetaminophen }\end{array}$ & \begin{tabular}{|c|} 
Group 1 \\
received $400 \mathrm{mg}$ \\
of ibuprofen 3 \\
times per day for \\
2 days \\
$\bullet$ Group 2 \\
received 500mg \\
acetaminophen \\
three times a day \\
for 2 days \\
Group3 (control- \\
)
\end{tabular} & $\begin{array}{c}\text { The maxillary } \\
\text { canines were } \\
\text { distalized with } \\
150 \mathrm{~g} \text { of force } \\
\text { delivered by } \\
\text { NiTi coil } \\
\text { springs }\end{array}$ & $\begin{array}{c}\text { GCF sampling } \\
\text { was done at } \\
\text { baseline and } \\
\text { after the } \\
\text { activation of the } \\
\text { springs at } 24,48 \\
\text { and } 168 \mathrm{~h} \text { using } \\
\text { micropipette }\end{array}$ & $\begin{array}{c}\bullet 7 \text { days } \\
\text { Observation time } \\
\text { - Follow up was } \\
\text { not clear }\end{array}$ & $\begin{array}{c}\text { The PGE2 levels } \\
\text { in the } 1^{\text {st }} \text { group } \\
\text { at } 24 \text { and } 48 \mathrm{~h} \\
\text { were } \\
\text { significantly less } \\
\text { when compared } \\
\text { to the } \\
\text { acetaminophen } \\
\text { and control } \\
\text { groups }\end{array}$ & $\begin{array}{l}\text { Ibuprofen inhibits } \\
\text { PGE2 synthesis } \\
\text { more than } \\
\text { acetaminophen }\end{array}$ \\
\hline
\end{tabular}




\begin{tabular}{|c|c|c|c|c|c|c|c|c|}
\hline Article & \begin{tabular}{|c|} 
Material: \\
Size, \\
Gender, \\
Age \\
(Years), \\
Dropout
\end{tabular} & Drug Used & \begin{tabular}{|c|} 
Dose and \\
Method of \\
Administration
\end{tabular} & $\begin{array}{l}\text { Methods of } \\
\text { Force } \\
\text { Application }\end{array}$ & $\begin{array}{c}\text { Method of } \\
\text { Measurement } \\
\text { of GCF/Tooth } \\
\text { Movement }\end{array}$ & $\begin{array}{c}\text { Observation } \\
\text { Time/Follow-up } \\
\text { Time }\end{array}$ & \begin{tabular}{|c|} 
Impact of \\
Medication on \\
Tooth \\
Movement
\end{tabular} & $\begin{array}{l}\text { Outcome/Author's } \\
\text { Conclusion }\end{array}$ \\
\hline $\begin{array}{l}\text { Karadeniz } \\
\text { et al., } \\
2011[28]\end{array}$ & $\begin{array}{c}\bullet \mathrm{N}=48 \\
\text { patients } \\
(23 \text { males, } \\
25 \\
\text { females }) \\
- \text { Mean } \\
\text { age: } 15.27 \\
- \text { No drop } \\
\text { out }\end{array}$ & Fluoride & $\begin{array}{c}\text { - Group } 1 \text { high } \\
\text { fluoride-heavy } \\
\text { force } \\
\text { - Group } 2 \text { low } \\
\text { fluoride-heavy } \\
\text { force } \\
\text { - Group } 3 \text { high } \\
\text { fluoride-light } \\
\text { force } \\
\text { - Group } 4 \text { low } \\
\text { fluoride-light } \\
\text { force } \\
\text { *Low fluoride } \\
\text { concentration } \\
\text { areas=0.05 ppm } \\
\text { *high fluoride } \\
\text { concentration } \\
\text { areas=2 ppm } \\
\text { respectively }\end{array}$ & $\begin{array}{l}\text { The patients' } \\
\text { maxillary first } \\
\text { premolars } \\
\text { were exposed } \\
\text { to either heavy } \\
(225 \mathrm{~g}) \text { or light } \\
(25 \mathrm{~g}) \text { forces } \\
\text { were applied } \\
\text { using Beta- } \\
\text { titanium } \\
\text { cantilever } \\
\text { springs }\end{array}$ & \begin{tabular}{|} 
2D and 3D \\
evaluation of \\
scanned casts \\
taken before \\
and 4 weeks \\
after activation \\
were \\
superimposed to \\
measure the \\
amount of \\
movement at \\
the buccal and \\
lingual cusps
\end{tabular} & $\begin{array}{c}\cdot 4 \text { weeks } \\
\text { treatment period } \\
\cdot \text { Follow up was } \\
\text { not clear }\end{array}$ & $\begin{array}{c}\text { 2D analysis: } \\
\text { G1HH: } 1.60 \mathrm{~mm} \\
\text { G2LH: } 1.33 \mathrm{~mm} \\
\text { G3HL: } 1.25 \mathrm{~mm} \\
\text { G4LL: } 1.02 \mathrm{~mm} \\
\\
\text { 3D analysis: } \\
\text { G1HH: } 1.61 \mathrm{~mm} \\
\text { G2LH: } 1.31 \mathrm{~mm} \\
\text { G3HL: } 1.15 \mathrm{~mm} \\
\text { G4LL: } 1.06 \mathrm{~mm}\end{array}$ & $\begin{array}{c}\text { - Fluoride and heavy } \\
\text { forces both increase } \\
\text { tooth movement. } \\
\text { - Two- and three- } \\
\text { dimensional methods } \\
\text { were accurate for the } \\
\text { assessment of tooth } \\
\text { movement after four } \\
\text { weeks of buccal } \\
\text { tipping force } \\
\text { application when the } \\
\text { palatal rugae were } \\
\text { used for } \\
\text { superimposition }\end{array}$ \\
\hline $\begin{array}{c}\text { Yamasaki } \\
\text { et al., } \\
1984[24] \\
\left(1^{\text {st }} \text { phase }\right)\end{array}$ & $\begin{array}{c}\bullet \mathrm{N}=9 \\
\text { cases } \\
(1 \text { male, } 8 \\
\text { females }) \\
\bullet \text { Mean } \\
\text { age: } 11.73 \\
- \text { No drop } \\
\text { out }\end{array}$ & $\begin{array}{l}\text { Prostaglandin } \\
\text { E1 }\end{array}$ & $\begin{array}{c}\bullet 10 \mu \mathrm{g} \text { PGE1 } \\
\text { was injected in } \\
\text { the submucosal } \\
\text { area of the buccal } \\
\text { side of the } \\
\text { maxillary first } \\
\text { premolar in the } \\
\text { experimental side } \\
\text { - A vehicle was } \\
\text { injected to the } \\
\text { control side }\end{array}$ & $\begin{array}{c}\text { Two double } \\
\text { springs were } \\
\text { adjusted to the } \\
\text { right and left } \\
\text { maxillary first } \\
\text { premolars with } \\
100 \mathrm{~g} \text { of force } \\
\text { in the buccal } \\
\text { direction }\end{array}$ & \begin{tabular}{|} 
Tooth \\
movement was \\
recorded by \\
measuring the \\
distances of the \\
first premolars \\
from the lingual \\
arches
\end{tabular} & $\begin{array}{c}\text { - Treatment time } \\
\text { was } 35 \text { days } \\
\text { - Follow up was } \\
\text { not clear }\end{array}$ & $\begin{array}{c}\text { - Prostaglandin } \\
\text { to control group } \\
\text { ratio was } 2.14: 1 \\
\text { - Average tooth } \\
\text { movement on } \\
\text { the PGE1 side } \\
3.02 \mathrm{~mm}\end{array}$ & $\begin{array}{c}\text { - Movement of the } \\
\text { experimental side } \\
\text { was almost doubled } \\
\text { with a ratio of } 2.14: 1 \\
\text { ratio } \\
\text { - No side effects } \\
\text { except for slight pain } \\
\text { in the first day on } \\
\text { both sides }\end{array}$ \\
\hline $\begin{array}{c}\text { Yamasaki } \\
\text { et al., } \\
1984[24] \\
\left(2^{\text {nd }} \text { phase }\right)\end{array}$ & $\begin{array}{c}\cdot \mathrm{N}=8 \\
\text { cases } \\
(2 \text { males, } \\
6 \text { females }) \\
- \text { Mean } \\
\text { age: } 12.55 \\
- \text { No drop } \\
\text { out }\end{array}$ & $\begin{array}{l}\text { Prostaglandin } \\
\text { E1 }\end{array}$ & \begin{tabular}{|c}
$10 \mu \mathrm{g}$ PGE1 \\
was injected in \\
the submucosal \\
area of the distal \\
side of the canine \\
in the \\
experimental side \\
over 2 weeks \\
- A vehicle was \\
injected to the \\
control side
\end{tabular} & $\begin{array}{l}\text { Maxillary and } \\
\text { Mandibular } \\
\text { canines of both } \\
\text { sides were } \\
\text { distalized with } \\
\text { sectional } \\
\text { contraction } \\
\text { loops archwire } \\
\text { using } 150 \mathrm{~g} \text { of } \\
\text { force }\end{array}$ & \begin{tabular}{|} 
Distal canine \\
movement was \\
considered as \\
the decrease of \\
the distance \\
between the \\
canine and the \\
anchor molars
\end{tabular} & $\begin{array}{c}\cdot 3 \text { weeks } \\
\text { treatment time } \\
\text { - Follow up was } \\
\text { not clear }\end{array}$ & $\begin{array}{c}\text { The treated side } \\
\text { showed greater } \\
\text { velocity of tooth } \\
\text { movement than } \\
\text { the untreated } \\
\text { side. }\end{array}$ & $\begin{array}{c}\bullet \text { In some cases, } \\
\text { tooth movement in } \\
\text { the experimental side } \\
\text { was doubled } \\
\text { - No side effects } \\
\text { were observed in the } \\
\text { PGE1 injected area }\end{array}$ \\
\hline $\begin{array}{c}\text { Yamasaki } \\
\text { et al., } \\
1984[24] \\
\left(3^{\text {rd }} \text { phase }\right)\end{array}$ & $\begin{array}{c}\bullet \mathrm{N}=8 \\
\text { cases } \\
(2 \text { males, } \\
6 \text { females }) \\
\cdot \text { Mean } \\
\text { age: } 18.55 \\
- \text { No drop } \\
\text { out }\end{array}$ & $\begin{array}{l}\text { Prostaglandin } \\
\text { E1 }\end{array}$ & $\begin{array}{c}\bullet 10 \mu \mathrm{g} \text { PGE1 } \\
\text { was injected in } \\
\text { the submucosal } \\
\text { area of the distal } \\
\text { side of the canine } \\
\text { in the } \\
\text { experimental side } \\
\text { over } 10 \text { days } \\
\text { - A vehicle was } \\
\text { injected to the } \\
\text { control side }\end{array}$ & $\begin{array}{l}\text { The maxillary } \\
\text { canines were } \\
\text { distalized with } \\
\text { compressed } \\
\text { open-coil } \\
\text { springs or } \\
\text { ringlets using } \\
150 \mathrm{~g} \text { force }\end{array}$ & \begin{tabular}{|} 
Distal canine \\
movement was \\
considered as \\
the decrease of \\
the distance \\
between the \\
canine and the \\
anchor molars
\end{tabular} & $\begin{array}{c}\cdot 10 \text { days } \\
\text { treatment period. } \\
\cdot \text { Follow up was } \\
\text { not clear }\end{array}$ & $\begin{array}{c}\text { - Prostaglandin } \\
\text { to control group } \\
\text { ratio was } 1.61: 1 \\
\text { - Average tooth } \\
\text { movement on } \\
\text { the PGE1 side } \\
2.07 \mathrm{~mm}\end{array}$ & $\begin{array}{c}\text { Tooth movement of } \\
\text { the experimental side } \\
\text { was more rapid } \\
\text { compared to control } \\
\text { side without any side } \\
\text { effects }\end{array}$ \\
\hline
\end{tabular}




\begin{tabular}{|c|c|c|c|c|c|c|c|c|}
\hline Article & $\begin{array}{c}\text { Material: } \\
\text { Size, } \\
\text { Gender, } \\
\text { Age } \\
\text { (Years), } \\
\text { Dropout }\end{array}$ & Drug Used & $\begin{array}{c}\text { Dose and } \\
\text { Method of } \\
\text { Administration }\end{array}$ & $\begin{array}{l}\text { Methods of } \\
\text { Force } \\
\text { Application }\end{array}$ & $\begin{array}{c}\text { Method of } \\
\text { Measurement } \\
\text { of GCF/Tooth } \\
\text { Movement }\end{array}$ & $\begin{array}{c}\text { Observation } \\
\text { Time/Follow-up } \\
\text { Time }\end{array}$ & \begin{tabular}{|c|} 
Impact of \\
Medication on \\
Tooth \\
Movement
\end{tabular} & $\begin{array}{c}\text { Outcome/Author's } \\
\text { Conclusion }\end{array}$ \\
\hline $\begin{array}{c}\text { Hussain et } \\
\text { al., 2011 } \\
{[23]}\end{array}$ & $\begin{array}{c}-\mathrm{N}=15 \\
\text { patients } \\
\text { - Age } \\
\text { range: } \\
17-28 \\
\text { No drop } \\
\text { out }\end{array}$ & Calcitriol & \begin{tabular}{|} 
• $15 \mu \mathrm{g}$ of \\
calciriol was \\
injected in the \\
distal side of the \\
maxillary canine \\
in the \\
experimental side \\
and 0.2 ml of \\
vehicle in the \\
control side \\
- $25 \mu \mathrm{g}$ of \\
calciriol was \\
injected in the \\
distal side of the \\
maxillary canine \\
in the \\
experimental side \\
and 0.2 ml of \\
vehicle in the \\
control side. \\
• $40 \mu \mathrm{g}$ of \\
calciriol was \\
injected in the \\
distal side of the \\
maxillary canine \\
in the \\
experimental side \\
and 0.2 ml of \\
vehicle in the \\
control side \\
$*$ These \\
injections were \\
repeated three \\
times for every \\
subject at 3 visits
\end{tabular} & $\begin{array}{l}\text { The right and } \\
\text { left maxillary } \\
\text { canines } \\
\text { retraction was } \\
\text { carried out in } \\
\text { the } 2^{\text {nd }} \text { phase } \\
\text { using SS base } \\
\text { archwire with } \\
\text { a distalizing } \\
\text { force of } 150 \mathrm{~g}\end{array}$ & \begin{tabular}{|} 
Tooth \\
movement was \\
measured using \\
digital vernier \\
as the distance \\
between the \\
maxillary \\
canine and $2^{\text {nd }}$ \\
premolar before \\
and after \\
treatment.
\end{tabular} & $\begin{array}{c}\text { - } 3 \text { weeks } \\
\text { treatment } \\
\text { - The follow up } \\
\text { period for every } \\
\text { patient included } \\
\text { five visits at one } \\
\text { week intervals }\end{array}$ & \begin{tabular}{|c|}
$25 \mu \mathrm{g}$ of \\
calcitriol \\
produces the \\
greatest tooth \\
movement when \\
compared to \\
control and \\
other groups: \\
$1.57 \pm 0.84 \mathrm{~mm}$
\end{tabular} & $\begin{array}{c}\text { - Calcitriol can } \\
\text { reduce treatment } \\
\text { time up to } 12 \text { weeks } \\
\text { without any side } \\
\text { effect } \\
\text { - In dose dependent } \\
\text { manner it can be a } \\
\text { cost-effective way to } \\
\text { accelerate OTM }\end{array}$ \\
\hline $\begin{array}{c}\text { Arantes et } \\
\text { al., 2009 } \\
{[22]}\end{array}$ & $\begin{array}{c}\cdot \mathrm{N}=36 \\
\text { patients } \\
\text { - Age } \\
\text { range: } \\
16-25 \\
\text { No drop } \\
\text { out }\end{array}$ & Tenoxicam & $\begin{array}{l}\text { - Group A } \\
\text { received 20mg } \\
\text { tablet before } \\
\text { activation and } \\
\text { placebo after } \\
\text { - Group B } \\
\text { received the } \\
\text { opposite } \\
\text { - Group C } \\
\text { received only } \\
\text { placebo before } \\
\text { and after }\end{array}$ & $\begin{array}{l}\text { Retraction of } \\
\text { the maxillary } \\
\text { canines was } \\
\text { carried out } \\
\text { using NiTi } \\
\text { springs }\end{array}$ & \begin{tabular}{|} 
Tooth \\
movement was \\
determined by \\
measuring the \\
distance \\
between the \\
canine and \\
second \\
premolar teeth \\
with a caliper
\end{tabular} & $\begin{array}{c}\cdot 30 \text { days } \\
\text { treatment period } \\
\text { - Follow up was } \\
\text { not clear }\end{array}$ & $\begin{array}{c}\text { OTM was } \\
\text { statistically } \\
\text { similar between } \\
\text { the tenoxicam \& } \\
\text { placebo groups }\end{array}$ & $\begin{array}{c}\text { Tenoxicam resulted } \\
\text { in reduction in pain } \\
\text { intensity without } \\
\text { alteration in tooth } \\
\text { movement }\end{array}$ \\
\hline $\begin{array}{l}\text { Mcgorray } \\
\text { et al., } \\
2011[21]\end{array}$ & $\begin{array}{c}\cdot \mathrm{N}=39 \\
\text { patients } \\
(11 \text { males, } \\
28 \\
\text { females }) \\
\cdot \text { Mean } \\
\text { age: } 26.9 \\
\cdot 4 \\
\text { patients } \\
\text { didn't } \\
\text { complete } \\
7 \text { or } 8 \text { of } 8 \\
\text { doses }\end{array}$ & Relaxin & $\begin{array}{c}-0.2 \mathrm{ml} \text { of relaxin } \\
\text { was injected to } \\
\text { the target teeth } \\
\text { weekly for } 8 \\
\text { weeks } \\
\text { - } 0.2 \mathrm{ml} \text { of } \\
\text { placebo was } \\
\text { injected to the } \\
\text { target teeth } \\
\text { weekly for } 8 \\
\text { weeks (control) }\end{array}$ & $\begin{array}{c}\text { A series of } 4 \\
\text { maxillary } \\
\text { aligners each } \\
\text { of them was } \\
\text { dispensed at } \\
\text { week } 0,2,4 \\
\text { and } 6 \text { to } \\
\text { produce } 2 \mathrm{~mm} \\
\text { for the selected } \\
\text { maxillary right } \\
\text { and left } \\
\text { canines }\end{array}$ & \begin{tabular}{|} 
Weekly PVS \\
impressions \\
were scanned \\
and \\
superimposed \\
according to \\
reference points
\end{tabular} & $\begin{array}{l}\cdot 8 \text { weeks } \\
\text { treatment time } \\
\text { - Evaluation of } \\
\text { retention (weeks } \\
\text { 9-12), then a } \\
\text { final visit at } \\
\text { week } 32 \text { for } \\
\text { safety }\end{array}$ & $\begin{array}{c}\text { Average tooth } \\
\text { movement over } \\
\text { the } 8 \text { weeks } \\
\text { period was } 0.83 \\
\text { mm for the } \\
\text { Relaxin group } \\
\text { and } 0.83 \mathrm{~mm} \text { for } \\
\text { the placebo } \\
\text { group }\end{array}$ & $\begin{array}{l}\text { - No difference in } \\
\text { tooth movement was } \\
\text { observed between } \\
\text { the } 2 \text { groups } \\
\text { - No difference in } \\
\text { relapse between both } \\
\text { groups at } 4 \text { weeks } \\
\text { follow up period }\end{array}$ \\
\hline
\end{tabular}




\begin{tabular}{|c|c|c|c|c|c|c|c|c|}
\hline Article & $\begin{array}{c}\text { Material: } \\
\text { Size, } \\
\text { Gender, } \\
\text { Age } \\
\text { (Years), } \\
\text { Dropout }\end{array}$ & Drug Used & $\begin{array}{c}\text { Dose and } \\
\text { Method of } \\
\text { Administration }\end{array}$ & $\begin{array}{l}\text { Methods of } \\
\text { Force } \\
\text { Application }\end{array}$ & $\begin{array}{c}\text { Method of } \\
\text { Measurement } \\
\text { of GCF/Tooth } \\
\text { Movement }\end{array}$ & $\begin{array}{c}\text { Observation } \\
\text { Time/Follow-up } \\
\text { Time }\end{array}$ & $\begin{array}{c}\text { Impact of } \\
\text { Medication on } \\
\text { Tooth } \\
\text { Movement }\end{array}$ & $\begin{array}{c}\text { Outcome/Author's } \\
\text { Conclusion }\end{array}$ \\
\hline $\begin{array}{l}\text { Patil et } \\
\text { al., 2005 } \\
{[25]}\end{array}$ & $\begin{array}{c}\bullet \mathrm{N}=15 \\
\text { patients } \\
(5 \\
\text { males, } 10 \\
\text { females }) \\
\cdot \text { Mean } \\
\text { age: } 17.78 \\
\cdot 1 \text { case } \\
\text { dropped } \\
\text { out }\end{array}$ & $\begin{array}{c}\text { Prostaglandin } \\
\text { E1 }\end{array}$ & $\begin{array}{c}\text { - } 1 \mathrm{~g} \text { of PGE1 was } \\
\text { injected in the } \\
\text { distal side of the } \\
\text { right maxillary } \\
\text { canine } \\
\text { - } 1 \mathrm{~g} \text { of } \\
\text { Lignocaine as a } \\
\text { vehicle was } \\
\text { injected in the } \\
\text { distal side of the } \\
\text { left maxillary } \\
\text { canine as a } \\
\text { control } \\
\text { *These injections } \\
\text { were repeated } \\
\text { three times for } \\
\text { every subject at } 3 \\
\text { visits (the } 1 \text { st } \\
\text { day, } 6^{\text {th }} \text { day and } \\
17^{\text {th }} \text { day of the } \\
\text { start of canine } \\
\text { retraction) }\end{array}$ & $\begin{array}{l}\text { Canine } \\
\text { retraction was } \\
\text { performed } \\
\text { using NiTi } \\
\text { retraction coil } \\
\text { springs with } \\
150 \mathrm{~g} \text { of light } \\
\text { continuous } \\
\text { force }\end{array}$ & \begin{tabular}{|} 
Occlusalgram \\
of pre and post \\
retraction \\
models were \\
superimposed \\
using specific \\
landmarks, \\
distance \\
traveled by tip \\
of canine was \\
measured with a \\
digital caliper
\end{tabular} & $\begin{array}{c}\cdot 60 \text { days } \\
\text { treatment } \\
\text { duration } \\
\text { - Follow up was } \\
\text { not clear }\end{array}$ & $\begin{array}{l}\text { - Mean value of } \\
\text { tooth movement } \\
\text { in the PGE1 } \\
\text { experimental } \\
\text { side was } 3.5 \mathrm{~mm} \\
\text { - Mean value of } \\
\text { tooth movement } \\
\text { in the control } \\
\text { side was } 2 \mathrm{~mm}\end{array}$ & $\begin{array}{l}\text { Significant increase } \\
\text { of tooth movement } \\
\text { of the experimental } \\
\text { canine compared to } \\
\text { the control canine } \\
\text { with a ratio of } 1.7: 1 \\
\text { and no side effects }\end{array}$ \\
\hline
\end{tabular}

With regards to other medications such as Relaxin it was found that injections of $0.2 \mathrm{ml}$ of Relaxin weekly over 8 weeks had no effect on tooth movement and was similar to the control group receiving placebo. This may be due to the small dosage used in this experiment as suggested by the authors.

Fluoride concentration may have an impact on orthodontic tooth movement as it was found that high fluoride intake patients had a higher rate of tooth movement than low fluoride patients under both heavy and light force application. Under heavy force, this rate was 22 percent higher while under light force it was 8 percent higher.

When comparing the three different doses of calcitriol, it was found that 25 micrograms were the most effective dose to accelerate tooth movement by $51 \%$ when compared to the experimental group. This may suggest that locally injected calcitriol in a specific dose is cost-effective measure for usage clinically to accelerate orthodontic tooth movement in humans. This acceleration in tooth movement can be attributed to the ability of calcitriol to stimulate bone resorption by induc-ing osteoclasts differentiation from their precursors [34].

A study carried out by Rajasekaran and Nayak comparing the effect of 100 microgram injections of PGE1 over 2 weeks period to cortectomy in 32 canines retraction and space closure patients suggest that cortectomy $(0.40 \mathrm{~mm} /$ week space closure $)$ is more effective than prostaglandin injection $(0.36 \mathrm{~mm} / \mathrm{week})$ in accelerating tooth movement, with no statistically significant differences between the two groups regarding the crestal bone height and root length changes [35]. However, as it can be seen above the amount of differences in tooth movement between the two groups $(0.04 \mathrm{~mm} /$ week $)$ does not seem to be clinically significant.

Older adults are at high risk of developing chronic conditions and disabilities such as diabetes, arthritis and cardiovascular diseases. Some animal studies suggest that regularly consumed drugs by the aged population can have a negative impact on orthodontic tooth movement such as metformin and beta blockers [36, 37]. As more adult patients are now seeking orthodontic treatment [38]. It's important to understand the mode of action of these drugs and their impact on the whole body including the bone, teeth and their supporting tissues. This will help the orthodontist to form an optimal treatment plan, including the intervals between the regular appointments to adjust the appliances. If a patient is taking a medication for chronic systematic condition which was shown to speed orthodontic tooth movement it may be prudent to shorten the intervals between the appointments to reduce the overall treatment time. If, on the other hand, the medication taken was shown to slow orthodontic tooth movement, then longer interval periods between the appointments will be appropriate to save the clinicians and patient's time without an impact on the overall duration of orthodontic treatment. Furthermore, drugs can be used during orthodontic treatment as a cost-effective measure to speed orthodontic tooth movement if proven to do so, especially those with no side-effects.

Most of the included studies in the current review failed to state the method of blinding and allocation concealment and thus they were of low quality. This, in addition to the heterogeneities between the studies including the use of different drugs and methods to measure tooth movement, made it not possible to combine their findings using a meta-analysis approach which represents the main shortcoming of this systematic review.

These results emphasize the need for further research including well designed randomized clinical trials to investigate the impact of commonly prescribed drugs during orthodontic treatment on orthodontic tooth movement and 
other non-invasive medications to increase the rate of orthodontic tooth movement.

\section{CONCLUSION}

- This review emphasizes the absence of high-quality evidence of the impact of drugs on orthodontic tooth movement. Bearing in mind the low quality of the evidence of the included studies, it was found that acetylsalicylic acid and ibuprofen reduced orthodontic tooth movement whereas paracetamol, Rofecoxib and tenoxicam had no impact on orthodontic tooth movement.

- It is the orthodontist's role to carefully record the medical and drug history of each patient in order to avoid further lengthening in the treatment time as well as to provide a successful treatment plan.

- To base our practice on scientific evidence, bettercontrolled RCTs are needed to investigate the impact of common medications on orthodontic tooth movement.

\section{CONSENT FOR PUBLICATION}

Not applicable.

\section{FUNDING}

None.

\section{CONFLICT OF INTEREST}

The authors declare no conflict of interest, financial or otherwise.

\section{ACKNOWLEDGEMENTS}

Declared none.

\section{REFERENCES}

[1] Goulet GC, Cooper DM, Coombe D, Zernicke RF. Influence of cortical canal architecture on lacunocanalicular pore pressure and fluid flow. Comput Methods Biomech Biomed Engin 2008; 11(4): 379-87. [http://dx.doi.org/10.1080/10255840701814105] [PMID: 185 68832]

[2] Krishnan V, Davidovitch Z. Cellular, molecular, and tissue-level reactions to orthodontic force. Am J Orthod Dentofacial Orthop 2006; 129(4): 469.e1-e32.

[http://dx.doi.org/10.1016/j.ajodo.2005.10.007] [PMID: 1662 7171]

[3] Wise GE, King GJ. Mechanisms of tooth eruption and orthodontic tooth movement. J Dent Res 2008; 87(5): 414-34. [http://dx.doi.org/10.1177/154405910808700509] [PMID: 184 34571]

[4] Arias OR, Marquez-Orozco MC. Aspirin, acetaminophen, and ibuprofen: Their effects on orthodontic tooth movement. Am J Orthod Dentofacial Orthop 2006; 130(3): 364-70.

[http://dx.doi.org/10.1016/j.ajodo.2004.12.027] [PMID: 169 79495]

[5] Bradley RL, Ellis PE, Thomas P, Bellis H, Ireland AJ, Sandy JR. A randomized clinical trial comparing the efficacy of ibuprofen and paracetamol in the control of orthodontic pain. Am J Orthod Dentofacial Orthop 2007; 132(4): 511-7. [http://dx.doi.org/10.1016/j.ajodo.2006.12.009] [PMID: 17920 505]

[6] Bernhardt MK, Southard KA, Batterson KD, Logan HL, Baker KA, Jakobsen JR. The effect of preemptive and/or postoperative ibuprofen therapy for orthodontic pain. Am J Orthod Dentofacial Orthop 2001; 120(1): $20-7$

[http://dx.doi.org/10.1067/mod.2001.115616] [PMID: 114553 73]

[7] Collins MK, Sinclair PM. The local use of vitamin D to increase the rate of orthodontic tooth movement. Am J Orthod Dentofacial Orthop 1988; 94(4): 278-84. [http://dx.doi.org/10.1016/0889-5406(88)90052-2] [PMID: 31 77281]

[8] Seifi M, Eslami B, Saffar AS. The effect of prostaglandin E2 and calcium gluconate on orthodontic tooth movement and root resorption in rats. Eur J Orthod 2003; 25(2): 199-204.

[http://dx.doi.org/10.1093/ejo/25.2.199] [PMID: 12737218]

[9] Liu ZJ, King GJ, Gu GM, Shin JY, Stewart DR. Does human relaxin accelerate orthodontic tooth movement in rats? Ann N Y Acad Sci 2005; 1041: 388-94.

[http://dx.doi.org/10.1196/annals.1282.059] [PMID: 15956736]

[10] Fujita S, Yamaguchi M, Utsunomiya T, Yamamoto H, Kasai K. Lowenergy laser stimulates tooth movement velocity via expression of RANK and RANKL. Orthod Craniofac Res 2008; 11(3): 143-55. [http://dx.doi.org/10.1111/j.1601-6343.2008.00423.x] [PMID: 18713151]

[11] Kawasaki K, Shimizu N. Effects of low-energy laser irradiation on bone remodeling during experimental tooth movement in rats. Lasers Surg Med 2000; 26(3): 282-91.

[http://dx.doi.org/10.1002/(SICI)1096-9101(2000)26:3<282::AID-LS M6>3.0.CO;2-X] [PMID: 10738291]

[12] Limpanichkul W, Godfrey K, Srisuk N, Rattanayatikul C. Effects of low-level laser therapy on the rate of orthodontic tooth movement. Orthod Craniofac Res 2006; 9(1): 38-43.

[http://dx.doi.org/10.1111/j.1601-6343.2006.00338.x] [PMID: 164202 73]

[13] Kakehi N, Yamazaki T, Tsugawa W, Sode K. A novel wireless glucose sensor employing direct electron transfer principle based enzyme fuel cell. Biosens Bioelectron 2007; 22(9-10): 2250-5. [http://dx.doi.org/10.1016/j.bios.2006.11.004] [PMID: 171667 11]

[14] Kolahi J, Abrishami M, Davidovitch Z. Microfabricated biocatalytic fuel cells: A new approach to accelerating the orthodontic tooth movement. Med Hypotheses 2009; 73(3): 340-1.

[http://dx.doi.org/10.1016/j.mehy.2009.03.041] [PMID: 19427 136]

[15] Anholm JM, Crites DA, Hoff R, Rathbun WE. Corticotomy-facilitated orthodontics. CDA J 1986; 14(12): 7-11.

[PMID: 3466718]

[16] Gantes B, Rathbun E, Anholm M. Effects on the periodontium following corticotomy-facilitated orthodontics. Case reports. J Periodontol 1990; 61(4): 234-8.

[http://dx.doi.org/10.1902/jop.1990.61.4.234] [PMID: 23249 23]

[17] Sukurica Y, Karaman A, Gürel HG, Dolanmaz D. Rapid canine distalization through segmental alveolar distraction osteogenesis. Angle Orthod 2007; 77(2): 226-36.

[http://dx.doi.org/10.2319/0003-3219(2007)077[0226:RCDTSA]2.0.C O;2] [PMID: 17319756]

[18] Kişnişci RS, Işeri H, Tüz HH, Altug AT. Dentoalveolar distraction osteogenesis for rapid orthodontic canine retraction. J Oral Maxillofac Surg 2002; 60(4): 389-94.

[http://dx.doi.org/10.1053/joms.2002.31226] [PMID: 119280 95]

[19] Higgins JP, Altman DG, Gøtzsche PC, et al. The Cochrane Collaboration's tool for assessing risk of bias in randomised trials. BMJ 2011; 343: d5928.

[http://dx.doi.org/10.1136/bmj.d5928] [PMID: 22008217]

[20] Balshem H, Helfand M, Schünemann HJ, et al. GRADE guidelines: 3. Rating the quality of evidence. J Clin Epidemiol 2011; 64(4): 401-6. [http://dx.doi.org/10.1016/j.jclinepi.2010.07.015] [PMID: 212 08779]

[21] McGorray SP, Dolce C, Kramer S, Stewart D, Wheeler TT. A randomized, placebo-controlled clinical trial on the effects of recombinant human relaxin on tooth movement and short-term stability. Am J Orthod Dentofacial Orthop 2012; 141(2): 196-203. [http://dx.doi.org/10.1016/j.ajodo.2011.07.024] [PMID: 22284 287]

[22] Arantes GM, Arantes VM, Ashmawi HA, Posso IP. Tenoxicam controls pain without altering orthodontic movement of maxillary canines. Orthod Craniofac Res 2009; 12(1): 14-9.

[http://dx.doi.org/10.1111/j.1601-6343.2008.01432.x] [PMID: 191542 70]

[23] Al-Hasani N, Glares G, Albustani A, Hussain S. Clinical efficacy of locally injected calcitriol in orthodontic tooth movement. Int J Pharm Pharm Sci 2011; 3(5): 139-43.

[24] Yamasaki K, Shibata Y, Imai S, Tani Y, Shibasaki Y, Fukuhara T. Clinical application of prostaglandin E1 (PGE1) upon ortho-dontic tooth movement. Am J Orthod 1984; 85(6): 508-18. [http://dx.doi.org/10.1016/0002-9416(84)90091-5] [PMID: 65 87784]

[25] Patil AK, Keluskar KM, Gaitonde SD. The clinical application of prostaglandin E1 on orthodontic tooth movement. J Indian Orthod Soc 2005; 38: 91-8.

[26] Sari E, Olmez H, Gürton AU. Comparison of some effects of acetylsalicylic acid and rofecoxib during orthodontic tooth movement. 
Am J Orthod Dentofacial Orthop 2004; 125(3): 310-5. [http://dx.doi.org/10.1016/j.ajodo.2003.04.006] [PMID: 1501 4407]

[27] Shetty N, Patil AK, Ganeshkar SV, Hegde S. Comparison of the effects of ibuprofen and acetaminophen on PGE2 levels in the GCF during orthodontic tooth movement: A human study. Prog Orthod 2013; 14(6): 6 .

[http://dx.doi.org/10.1186/2196-1042-14-6] [PMID: 24325834]

[28] Karadeniz EI, Gonzales C, Elekdag-Turk S, et al. The effect of fluoride on orthodontic tooth movement in humans. A two- and threedimensional evaluation. Aust Orthod J 2011; 27(2): 94-101.

$$
\text { [PMID: 22372264] }
$$

[29] Bartzela T, Türp JC, Motschall E, Maltha JC. Medication effects on the rate of orthodontic tooth movement: A systematic literature review. Am J Orthod Dentofacial Orthop 2009; 135(1): 16-26.

[http://dx.doi.org/10.1016/j.ajodo.2008.08.016] [PMID: 1912 1496]

[30] Makrygiannakis MA, Kaklamanos EG, Athanasiou AE. Does common prescription medication affect the rate of orthodontic tooth movement? A systematic review. Eur J Orthodont 2018; 1-11.

[31] Goodson JM, McClatchy K, Revell C. Prostaglandin-induced resorption of the adult rat calvarium. J Dent Res 1974; 53: 670-7. [http://dx.doi.org/10.1177/00220345740530032601]

[32] Yamasaki K, Miura F, Suda T. Prostaglandin as a mediator of bone resorption induced by experimental tooth movement in rats. J Dent Res 1980; 59(10): 1635-42. [http://dx.doi.org/10.1177/00220345800590101301] [PMID: 6932420]

33] Kim JH, Lee YH, Im SA, Kim K, Lee CK. Cyclooxygenase inhibitors, aspirin and ibuprofen, inhibit MHC-restricted antigen presentation in dendritic cells. Immune Netw 2010; 10(3): 92-8.

[34] Collins MK, Sinclair PM. The local use of vitamin D to increase the rate of orthodontic tooth movement. Am J Orthod Dentofacial Orthop 1988; 94(4): 278-84.

[http://dx.doi.org/10.1016/0889-5406(88)90052-2] [PMID: 3177281]

[35] Rajasekaran UB, Krishna Nayak US. Effect of prostaglandin E1 versus corticotomy on orthodontic tooth movement: An in vivo study. Indian J Dent Res 2014; 25(6): 717-21.

[http://dx.doi.org/10.4103/0970-9290.152170] [PMID: 25728 102]

[36] Sun J, Du J, Feng W, et al. Histological evidence that metformin reverses the adverse effects of diabetes on orthodontic tooth movement in rats. J Mol Histol 2017; 48(2): 73-81.

[http://dx.doi.org/10.1007/s10735-016-9707-y] [PMID: 27981 392]

[37] de Oliveira EL, Freitas FF, de Macedo CG, et al. Low dose propranolol decreases orthodontic movement. Arch Oral Biol 2014; 59(10): 1094-100.

[http://dx.doi.org/10.1016/j.archoralbio.2014.06.006] [PMID: 250333 80]

[38] Mavreas D, Athanasiou AE. Orthodontics and its interactions with other dental disciplines. Prog Orthod 2009; 10(1): 72-81. [PMID: 19506747]

\section{2019 Khalaf and Mando.}

This is an open access article distributed under the terms of the Creative Commons Attribution 4.0 International Public License (CC-BY 4.0), a copy of which is available at: (https://creativecommons.org/licenses/by/4.0/legalcode). This license permits unrestricted use, distribution, and reproduction in any medium, provided the original author and source are credited. 